\title{
ANALISIS KEPUASAN PELANGGAN TERHADAP IMPLEMENTASI ISO 9001:2015 DENGAN MENGGUNAKAN PENDEKATAN SERVQUAL (STUDI KASUS: INSTITUT TEKNOLOGI TELKOM PURWOKERTO)
}

\section{Analysis of Customer Satisfaction on ISO 9001: 2015 Implementation using Servqual Approach (Case Study: Institut Teknologi Telkom Purwokerto)}

\author{
Yudi Syahrullah $^{1 *}$, Atik Febriani ${ }^{1}$, Bunga Zati Hulwani ${ }^{1}$ \\ ${ }^{1}$ Program Studi Teknik Industri, Fakultas Teknologi Industri dan Informatika, Institut Teknologi Telkom \\ Purwokerto
}

Diterima: 1 Agustus 2018 / Disetujui: 20 Agustus 2018

\begin{abstract}
September 2018 is the deadline for an organization that has implemented an international standard quality management system ISO 9001: 2008 to switch the latest international standard ISO 9001: 2015. Telkom Institute of Technology Purwokerto is one of the organizations that have implemented the international standard ISO 9001: 2015 since early 2017 (Previously ISO 9001: 2008 implementation). The main objectives of the implementation of ISO 9001 are to improve customer satisfaction both external and internal, including students as the main user of the service organization as an external customer. Therefore, this organization needs to measure the level of student satisfaction with services provided by Telkom Institute of Technology Purwokerto after the organization is implementing ISO 9001: 2015. Data were collected using the questionnaire method consists of 24 questions that designed and analyzed by the SERVQUAL approach. Validity and reliability testing were done by using SPSS software and the measurement result of 24 question items stated Valid and Reliable. From the preliminary research, it was found that the institution should introduce ISO 9001: 2015 to the students at Telkom Institute of Technology Purwokerto. Using the SERVQUAL approach and analyzing GAP 5, comparing the expectations and perceptions of customers (students), the result is that organizations need to improve the speed of the service (academic/student affairs/staff) to students (GAP Value 1.11). In addition, institutions also need to increase the attention of students (GPA Value 1.06). Several efforts have been made with the construction of facilities such as a lecture building that continues to be implemented as well as changes in organizational structure to improve the quality of academic and non-academic services to students.
\end{abstract}

Keywords: Quality Management System, Customer Satisfaction, ISO 9001:2015, SERVQUAL

\section{ABSTRAK}

Bulan September tahun 2018 merupakan batas akhir suatu organisasi yang telah mengimplementasikan sistem manajemen mutu standar internasional ISO 9001: 2008 untuk beralih menggunakan standar internasional versi terbaru ISO 9001: 2015. Institut Teknologi Telkom Purwokerto merupakan salah satu organisasi yang telah melakukan implementasi standar internasional ISO 9001: 2015 sejak awal tahun 2017 (Sebelumnya implementasi ISO 9001: 2008). Tujuan utama dari implementasi ISO 9001 salah satunya adalah meningkatkan kepuasan pelanggan baik eksternal maupun internal, termasuk mahasiswa sebagai user utama dari pelayanan organisasi sebagai pelanggan eksternal. Oleh karena itu, organisasi ini perlu mengukur tingkat kepuasan mahasiswa terhadap layanan yang diberikan oleh Institut Teknologi Telkom Purwokerto setelah organisasi ini melakukan implementasi ISO 9001: 2015. Pengumpulan data dilakukan dengan menggunakan metode kuesioner dengan pertanyaan yang dirancang dan dianalisis dengan pendekatan SERVQUAL. Uji validitas dan reliabilitas dilakukan dengan menggunakan perangkat lunak SPSS dan hasilnya hasil pengukuran untuk 24 item pertanyaan dinyatakan valid dan reliabel. Dari penelitian awal diperoleh hasil bahwa institusi perlu mengenalkan ISO 9001: 2015 kepada para Mahasiswa di Institut Teknologi Telkom Purwokerto. Dengan menggunakan pendekatan SERVQUAL dan melakukan analisis GAP 5, yaitu membandingkan antara harapan dan ekspektasi pelanggan (mahasiswa), diperoleh hasil bahwa institusi perlu memperbaiki kecepatan dari bagian pelayanan (tenaga akademik/kemahasiswaan/staff) kepada Mahasiswa (Nilai GAP 1.11). Selain itu institusi juga perlu meningkatkan perhatian terhadap mahasiswa (Nilai GAP 1.06). Beberapa upaya telah dilakukan dengan pembangunan fasilitas seperti gedung perkuliahan yang terus dilaksanakan serta perubahan struktur organisasi untuk meningkatkan mutu pelayanan akademik dan non akademik kepada mahasiswa.

Kata Kunci: Sistem Manajemen Mutu, Kepuasan Pelanggan, ISO 9001: 2015, SERVQUAL

*email: yudi@ittelkom-pwt.ac.id 


\section{PENDAhUluan}

Implementasi sistem manajemen mutu (SMM) berupaya untuk meningkatkan mutu dan kepuasan pelanggan baik internal maupun eksternal dari sebuah organisasi. Salah satu bentuk implementasi sistem manajemen mutu yang terkenal didunia adalah ISO 9001. Standar ISO 9001 telah diimplementasikan diberbagai belahan dunia. Perusahaan-perusahaan di Indonesia telah banyak yang mengimplementasikan sistem manajemen mutu dengan melakukan sertifikasi 9001. Organisasi - organisasi tersebut berupaya menerapkan semua persyaratan yang ada didalam standar internasional manajemen mutu tersebut untuk memperoleh sertifikasi ISO 9001.

Dahulu ISO 9001 diterapkan oleh berbagai industri khususnya manufaktur. Industri manufaktur menerapkan sistem manajemen mutu ISO 9001 untuk meyakinkan pelanggan bahwa produk yang mereka hasilkan sudah terjamin mutunya dari awal proses hingga proses akhir didalam organisasi tersebut. Industri manufaktur ini juga meyakinkan bahwa semua proses dilakukan berdasarkan standar manajemen mutu internasional. Sehingga produk yang dihasilkan dapat memenuhi kebutuhan permintaan dalam skala internasional. Seiring berkembangnya dunia industri, saat ini ISO 9001 bukan hanya diimplementasikan pada industri manufaktur, tetapi juga diimplementasikan pada bidang jasa, seperti: rumah sakit, institusi pendidikan, pengiriman dan lain-lain. Bahkan saat ini ada beberapa organsasi non-profit menerapkan sistem manajemen mutu ISO 9001, diantaranya: Dinas Kesehatan, Dinas Sosial dan Institusi pemerintahan lainnya. Organisasi ini menganggap penerapan ISO 9001 dapat memperbaiki kinerja pelayanan organisasi terhadap pelanggan dalam hal ini adalah masyarakat umum, sehingga diharapkan kepuasan masyarakat terhadap pelayanan yang diberikan akan meningkat.

Saat ini merupakan masa transisi perubahan standar ISO 9001 versi lama 2008 (ISO 9001: 2008) menjadi standar baru versi 2015 (ISO 9001: 2015). Badan standarisasi internasional ISO telah menerbitkan Standar ISO 9001 versi 2015 untuk memperbaharui standar lama ISO 9001 versi 2008. Persyaratan ISO 9001:2015 telah diterbitkan sejak tahun 2015 dan organisasi yang masih menerapkan standar lama ISO 9001: 2008 diberikan kesempatan paling lambat 3 tahun setelah tahun 2015 untuk menggunakan standar lama tersebut. Tahun ini (bulan September) merupakan batas akhir untuk perubahan standar ISO 9001: 2015. Hal tersebut menunjukkan bahwa organisasi harus siap menghadapi tantangan terbaru dalam implementasi sistem manajemen mutu versi baru ini.

Institut Teknologi Telkom Purwokerto mulai menerapkan standar manajemen mutu ISO 9001: 2015 sejak tahun 2017 dan merupakan tahun yang sama dengan pendirian Institut Teknologi Telkom Purwokerto (sebelumnya masih berstatus sekolah tinggi). Perubahan status tersebut berdampak besar terhadap struktur organisasi dan sistem manajemen secara keseluruhan dalam organisasi ini. Perlu perhatian khusus terhadap implementasi ISO 9001: 2015 terhadap kaitannya dengan kepuasan pelanggan dalam hal ini mahasiswa sebagai pelanggan utama dari organisasi.

Saat ini institusi telah dinyatakan layak memperoleh sertifikat ISO 9001: 2015 setelah melalui proses audit eksternal. Organisasi berharap dengan implementasi ISO 9001: 2015 dapat lebih meningkatkan performa dari organisasi, seperti: meningkatnya kepuasan pelanggan (internal dan eksternal), tercapainya sasaran organisasi, serta yang cukup penting adalah organisasi harus siap dengan perkembangan dan perubahan internal maupun eksternal. Selama masa perubahan institusi dari Sekolah tinggi menjadi Institut Teknologi seperti saat ini, banyak proses pelayanan kepada pelanggan yang harus mberubah mengikut aturan baru. Hal ini tentu saja akan berpengaruh terhadap kepuasan mahasiswa dalam menerima layanan dan fasilitas lainnya dari institusi.

Penelitian terkait implementasi ISO 9001 versi 2008 telah banyak dilakukan oleh peneliti sebelumnya (Ingason, 2015; Sumaedi dan Yarmen, 2015). Sementara terkait implementasi ISO 9001: 2015 masih sedikit penelitian terkait hal ini. Penelitian terdahulu dilakukan untuk meneliti proses persiapan implementasi ISO 9001: 2015 (Sindhuwinata dan Felecia, 2016), belum melihat hasil implementasi standar internasional tersebut. Penelitian ini dilakukan untuk mengetahui kepuasan mahasiswa terhadap Institut Teknologi Telkom Purwokerto. Penelitian ini fokus untuk mengukur harapan dan ekspektasi pelanggan (mahasiswa) terhadap layanan dan fasilitas dari Institut Teknologi Telkom Purwokerto.

\section{TINJAUAN PUSTAKA}

\subsection{Sistem Manajemen Mutu dan Standar Internasional}

Sistem Manajemen Mutu (SMM) merupakan sekumpulan prosedur terdokumentasi dan praktek-praktek standar manajemen sistem yang bertujuan untuk menjamin kesesuaian dari suatu proses dan produk terhadap kebutuhan atau persyaratan tertentu yang ditetapkan oleh pelanggan dan pasar (Semuel dan Zulkarnain, 2011). Untuk memastikan bahwa organisasi telah menerapakan sistem manajemen mutu sesuai dengan keinginan pelanggan, maka sebuah badan organisasi internasional ISO menerbitkan aturan atau persayaratan yang terdokumentasi tentang sistem manajemen kualitas

ISO merupakan sebuah organisasi untuk standar internasional yang berlokasi di Jenewa, 
Swiss. ISO berasal dari bahasa Yunani yaitu IOS yang artinya sama atau standar. Standar ISO dikembangkan agar standar internasional untuk dokumentasi sistem kualitas dapat diterapkan pada berbagai jenis industri. Standar ISO sangat luas dan tidak spesifik sehingga dapat diterapkan pada berbagai jenis industri yang berbeda-beda (Foster, 2016). Standar ISO diterbitkan di Eropa salah satunya untuk menghadapi persaingan produk-produk berkualitas dari Jepang. Sehingga untuk memastikan bahwa sistem kualitas dari sebuah industri sudah terjamin hasilnya diterbitkan Standar ISO 9000. Standar ISO 9000 dikeluarkan untuk membantu perusahaan mendokumentasikan sistem kualitas dan untuk mengendalikan ketidak sesuaian yang terjadi didalam sebuah organisasi.

\subsection{Impelementasi ISO 9001}

Sistem mutu ISO 9000 merupakan standar kualitas internasional yang pada awalnya diterapkan pada bidang industri untuk dapat menghasilkan produk yang sesuai standar (persyaratan dari pelanggan) dan sudah terjamin prosesnya menurut acuan standar internasional (Soerjaningsih, 2004). Awal terbentuknya standar internasional untuk sistem kualitas menggunakan kode ISO 9000, selanjutnya terjadi perubahan isi standar dan berubah menjadi ISO 9001. Penelitian terkait ISO 9000/9001 telah banyak dilakukan (Ingason, 2015; Sumaedi dan Yarmen, 2015).

Komitmen dan partisipasi TOP manajemen, partisipasi dan keterlibatan langsung dari karyawan serta perencanaan dan penetapan sasaran yang baik merupakan kunci keberhasilan dari implementasi ISO 9001 maupun standar internasional lainnya (Ingason, 2015). Perencanaan biaya untuk implementasi ISO juga memberikan kontribusi yang penting dalam kesuksesan sertifikasi ISO 9001. Komitmen dan partisipasi manajemen bisa dilihat dari anggaran yang direncanakan dalam implementasi ISO 9001. Organisasi yang merencanakan anggaran implementasi dapat memperoleh sertifikasi dalam jangka waktu yang lebih cepat dibandingkan yang tidak merencakan anggaran (Ingason, 2015). Seiring dengan berkembangnya kebutuhan organisasi, ISO 9001 tidak hanya diimplementasikan pada bidang industri yang menghasilkan produk saja, tetapi juga diimplementasikan pada bidang jasa, seperti: pendidikan, rumah sakit dan instansi pemerintahan.

\subsection{Impelementasi ISO pada Bidang Jasa}

Pada institusi pendidikan ISO 9001 dapat menjamin tercapainya tiga kriteria Badan Akreditasi Nasional (BAN) yaitu mutu, relevansi dan efisiensi yang merupakan dimensi ukuran dari input, proses dan output (Soerjaningsih, 2004). Sebagai contoh pada ISO 9001, organisasi diminta untuk melakukan pemantauan sasaran mutu yang perlu digambarkan dalam rencana mutu, prosedur dan instruksi kerja.

Implementasi ISO 9001 pada bidang pendidikan mengacu pada konsep Plan-DoCheck-Action (PDCA). Implementasi ISO 9001 membantu Sekolah Menengah Kejuaruan dalam membuat perencanaan mulai dari penyusunan silabus, pembagian tugas mengajar, penyusunan Rencana Pembelajaran (RPP), jobsheet, presensi, daftar nilai hingga agenda pembelajaran (Ulfi, Sudjimat dan Wibawanto, 2012). Akan tetapi, kesadaran guru dalam impelementasi ISO 9001 masih rendah dan perlu ditingkatkan. Kedisiplinan dalam memenuhi persyaratan dokumentasi ISO 9001 seharusnya dapat membantuk sekolahsekolah dalam memenuhi dokumentasi untuk persayaratan akreditasi sekolah.

Sistem manajemen mutu ISO 9001 juga banyak diimplementasikan pada bidang kesehatan. Penelitian terdahulu mengimplementasikan sistem manajemen mutu ISO 9001 pada Dinas Kesehatan Kota Tarakan dengan berfokus pada menetapkan suatu komitmen pada top manajemen, mendefinisikan struktur organisasi dan tanggung jawab, menciptakan kesadaran kualitas pada semua tingkat organisasi, mendokumentasikan aktivitas rinci melalui prosedur dan instruksi kerja, melakukan tinjauan manajemen dan memantau kualitas pelayanan dari dinas kesehatan Kota Tarakan (Qolbi, 2014). Hasilnya, sistem manajemen mutu ISO 9001 mampu meningkatkan kepuasan pelanggan dalam pemenuhan keinginan dan kebutuhan pelanggan bagi pengguna jasa pelayanan (Qolbi, 2014).

Sementara itu, implementasi sistem manajemen mutu ISO 9001 pada Puskesmas di wilayah kerja Dinas Kesehatan Kabupaten Sleman dapat membantu Puskesmas dalam mereformasi kebijakan dan birokrasi yang sangat menguntungkan untuk dinas tersebut (Nuryati, 2017). Dengan implementasi ISO 9001 Puskesmas dapat memenuhi sarana dan prasarana sesuai kebutuhan pasien (pelanggan) karena kelengkapan sarana dan prasarana juga diatur dalam persyaratan ISO 9001. Selain itu ISO 9001 membantu Puskesmas dan Dinas Kesehatan dalam memperbaiki sistem informasi yang memadai sesuai kebutuhan pelanggan.

\subsection{Impelementasi ISO 9001: 2015}

Penelitian tentang implementasi ISO 9001: 2015 di Indonesia belum banyak dilakukan oleh para peneliti di Indonesia. Penelitian terkait ISO 9001: 2015 membahas tentang perancangan sistem manajemen mutu ISO 9001: 2015 pada perusahaan manufaktur yang bergerak dalam bidang consumer goods (Sindhuwinata dan Felecia, 2016) dan tentang Implementasi manajemen risiko berbasis ISO 9001: 2015 pada 
usaha jasa konsultasi (Hadisaputra dan Kusumah, 2017).

Risiko dari seluruh aktivitas diamati untuk bagian SDM (Compensation \& Benefit) yang berjumlah 127 proses (Sindhuwinata dan Felecia, 2016). Sebanyak 55 proses memberikan dampak yang cukup signifikan untuk organisasi. Implementasi ISO 9001: 2015 sudah $86 \%$ dilakukan dan unit ini perlu melakukan perbaikan berkelanjutan untuk efektivitas sistem manajemen mutu. Mitigasi risiko dan peluang dapat diperoleh sesuai dengan isu-isu dan sasaran yang ingin dicapai oleh organisasi (Hadisaputra dan Kusumah, 2017). Hasilnya, PT. BSU perlu melakukan optimalisasi peran website dan pemasaran untuk mencapai sasaran yang ingin dicapai oleh organisasi.

Salah satu tujuan utama ISO 9001 adalah untuk meningkatkan kepuasan pelanggan, baik internal maupun eksternal. Oleh karena itu organisasi perlu melakukan pengamatan terdapat kepuasan pelanggan terhadap implementasi ISO 9001: 2015. Hal ini menjadi dasar untuk penelitian kepuasan pelanggan pada institutsi yang telah melakukan implementasi ISO 9001: 2015, salah satunya Institut Teknologi Telkom Purwokerto. Ada beberapa metode yang dilakukan untuk mengukur kepuasan pelanggan, salah satu metode yang sering digunakan adalah metode SERVQUAL.

\subsection{SERVQUAL}

SERVQUAL merupakan sebuah alat yang dikembangkan untuk melakukan penilaian atau asesmen terhadap kualitas pelayanan dan telah banyak digunakan oleh berbagai perusahaan untuk melakukan penilaian untuk berbagai macam situasi pelayanan (Zeithaml, Berry dan Parasuraman, 1990; Foster, 2016). Beberapa keuntungan menggunakan metode SERVQUAL diantaranya:

a. Dapat dijadikan standar dalam melakukan penilaian untuk mengukur dimensi kualitas dari pelayanan yang berbeda-beda

b. Telah terbukti valid untuk sejumlah situasi pelayanan

c. Telah terbukti handal (reliable) yang berarti pembaca yang berbeda-beda dapat menafsirkan pertanyaan - pertanyaan serupa

d. Instrument pertanyaan yang terdiri dari 22 item membuat kuesioner dapat diisi dengan cepat

e. Merupakan sebuah alat yang sudah standar untuk mengukur persepsi kualitas layanan

SERVQUAL dibangun atas adanya perbandingan dua faktor utama, yaitu persepsi pelanggan atas layanan nyata yang mereka terima (perceived service) dengan layanan yang sesungguhnya yang diharapkan/diinginkan (expected service). Jika kenyataan lebih dari yang diharapkan, maka layanan dapat dikatakan bermutu, sedangkan jika kenyataan kurang dari yang diharapkan, maka layanan dikatakan tidak bermutu. Apabila kenyataan (persepsi) sama dengan harapan (ekspektasi) maka layanan tersebut dapat dikatakan memuaskan atau sangat memuaskan. Kualitas layanan dipandang sebagai konsep multi dimensi. Konsumen menilai dan mengevaluasi sejumlah faktor atau dimensi. 10 dimensi umum yang mewakili kriteria penilaian kualitas pelayanan antara lain (1) Tangibles; (2) Reliability; (3) Responsiveness; (4) Competence; (5) Courtesy; (6) Credibility; (7) Security; (8) Acces; (9) Communication dan Understanding the customer.

Pada SERVQUAL, 7 dimensi terakhir diklasifikasikan ke dalam 2 dimensi yang lebih luas, yaitu assurance dan empathy, Sehingga dimensi dalam SERVQUAL disederhanakan menjadi lain (1) Tangibles; (2) Reliability; (3) Responsiveness; (4) Assurance dan (5) Empathy. Metode SERVQUAL digunakan untuk mengetahui kesenajangan (GAP) antara persepsi dan keingingan pelanggan berdasarkan lima dimensi kualitas, yaitu: tangible, reliability, responsiveness, empathy dan assurance (Dharmawan dan Wurjaningrum, 2014). 5 GAP yang menyebabkan kegagalan penyampaian jasa, yaitu:

a. GAP antara harapan konsumen dan persepsi manajemen.

b. GAP antara persepsi manajemen terhadap harapan konsumen dan spesifikasi kualitas jasa.

c. GAP antara spesifikasi kualitas jasa dan penyampaian jasa.

d. GAP antara penyampaian jasa dan komunikasi eksternal.

e. GAP antara jasa yang dirasakan dan jasa yang diharapkan oleh konsumen.

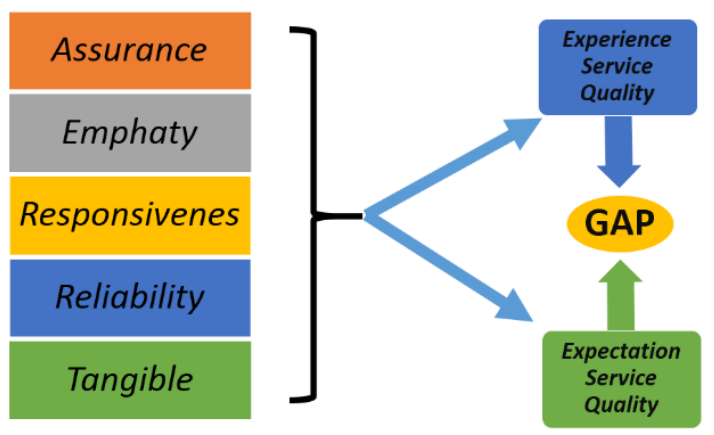

Gambar 1. Framework Konseptual SERVQUAL Sumber: (Qadri, 2015)

Kualitas merupakan salah satu indikator penting bagi perusahaan atau organisasi untuk dapat tetap bertahan di tengah ketatnya persaingan dalam industri. Menurut Kamus Besar Bahasa Indonesia (KBBI), kualitas berarti tingkat baik buruknya sesuatu, derajat atau taraf mutu. Berkualitas diartikan bahwa sesuatu mempunyai kualitas atau mutu yang baik. 
Salah satu faktor yang berpengaruh terhadap kepuasan konsumen adalah kualitas produk. Kualitas produk ditentukan berdasarkan kegunaan dan fungsinya, termasuk kinerja, daya tahan, kesesuaian dengan spesifikasi, estetika produk, dan juga kesan produk (perceived quality) Produk dengan kualitas yang bagus dan terpercaya senantiasa tertanam dibenak konsumen, karena konsumen bersedia membayar sejumlah uang untuk membeli produk tersebut. Meskipun produk tersebut mempunyai kualitas yang baik, hal tersebut belum tentu membuat konsumen puas. Selain kualitas produk, kepuasan konsumen juga tergantung pada kualitas layanan yang ditawarkan oleh perusahaan. Kualitas layanan adalah setiap tindakan atau kegiatan yang ditawarkan oleh satu pihak kepada pihak lain, biasanya tidak berwujud (Kotler dan Keller, 2016).

\section{METODOLOGI}

Penelitian ini dilakukan dengan langkahlangkah pada Gambar 2.

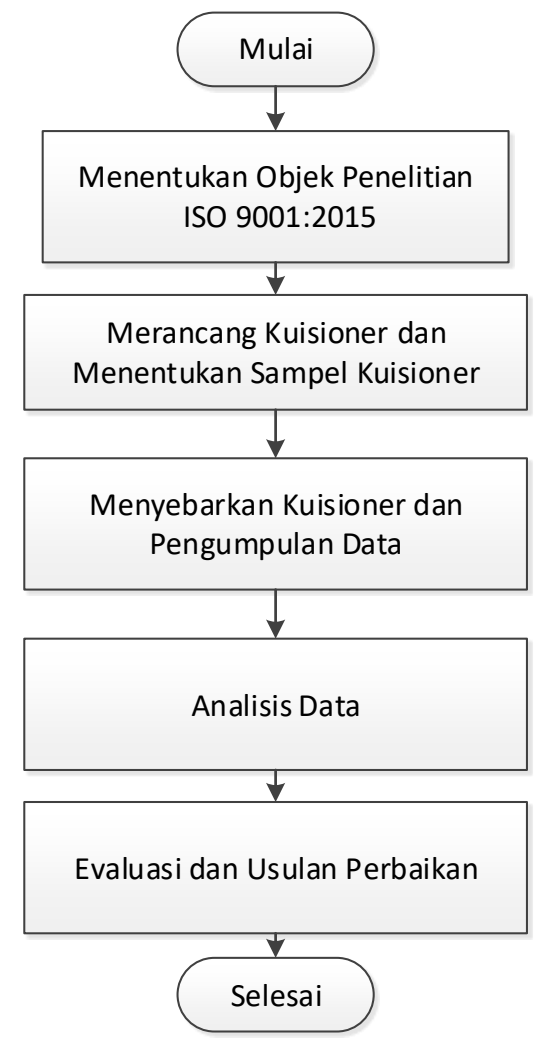

Gambar 2. Metodologi Penelitian

a. Objek penelitian

Penelitian dilakukan pada Institut Teknologi Telkom Purwokerto sebagai organisasi yang telah melakukan implementasi ISO 9001: 2015. Peubah yang diamati adalah hasil kepuasan mahasiswa setelah Institut Teknologi Telkom Purwokerto mengimplementasikan ISO 9001: 2015.

b. Perancangan Kuesioner dan Sampel

1) Kuesioner yang disebarkan terdiri atas 2 jenis, yaitu harapan pelanggan dan ekspektasi pelanggan terhadap layanan institusi.
2) Penelitian ini dilakukan dengan menggunakan kuesioner dan wawancara terhadap beberapa mahasiswa Institut Teknologi Telkom Purwokerto tingkat 2 keatas ( $\geq$ Semester 4$)$

3) Kuesioner dirancang berdasarkan alat yang digunakan untuk melakukan penilaian kepuasan pelanggan, yaitu SERVQUAL dengan fokus terhadap analisis GAP 5

4) Uji kecukupan data dilakukan dengan menggunakan rumus Slovin sebagai berikut (Cendy, Sugiono dan Hardiningtyas, 2015):

$$
n^{\prime}=\frac{N}{1+N e^{2}}
$$

\section{Keterangan:}

$n^{\prime}=$ Jumlah sampel yang harus diambil

$N=$ Jumlah populasi

$e=$ Margin of Error

c. Penyebaran kuesioner dan pengumpulan data dilakukan pada masa semester genap tahun ajaran 2017 / 2018 kepada mahasiswa yang telah menyelesaikan perkuliahan di Institut Teknologi Telkom minimal 1 tahun (2 Semester)

d. Analisis data

1) Validasi data dan uji reliabilitas menggunakan perangkat lunak SPSS. Uji validitas menggunakan korelasi Bivariate Pearson, sementara uji reliabilitas menggunakan rumus Alpha Cronbach.

2) Selanjutnya data diolah dengan pendekatan SERVQUAL untuk menganalisis GAP 5, yaitu kesenjangan antara Ekspektasi dan Persepsi Pelanggan

e. Evaluasi dan saran perbaikan diberikan berdasarkan hasil analisis GAP 5 dari kuesioner yang telah disebarkan

\section{HASIL DAN PEMBAHASAN}

\subsection{Identifikasi Atribut Kualitas dan Jasa}

Atribut pelayanan yang dijadikan sebagai item pertanyaan yang disurvey kepada pelanggan berdasarkan 5 dimensi yang digunakan dalam metode SERVQUAL pada Tabel 1.

Tabel 1. Atribut Pelayanan yang Disurvey

\begin{tabular}{|c|c|c|}
\hline No & Dimensi & Atribut Pelayanan \\
\hline 1 & Tangible & $\begin{array}{l}\text { Institusi Telah Menyediakan } \\
\text { Perlengkapan atau Peralatan } \\
\text { (Kelas/Laboratorium/Perpustak } \\
\text { aan) yang Modern }\end{array}$ \\
\hline 2 & & $\begin{array}{l}\text { Jumlah Petugas pelayanan } \\
\text { akademik dan kemahasiswaan } \\
\text { sudah sesuai dengan kebutuhan }\end{array}$ \\
\hline 3 & & $\begin{array}{l}\text { Kebersihan dan Kenyamanan } \\
\text { Kampus memadai (Kelas, Toilet } \\
\text { dan Area Sekitar Kampus) }\end{array}$ \\
\hline 4 & & $\begin{array}{l}\text { Fasilitas fisik } \\
\text { (Gedung/Kelas/Laboratorium/P } \\
\text { erpustakaan) terlihak menarik }\end{array}$ \\
\hline
\end{tabular}




\begin{tabular}{|c|c|c|c|c|c|}
\hline No & Dimensi & Atribut Pelayanan & No & Dimensi & Atribut Pelayanan \\
\hline \multirow[t]{2}{*}{5} & & $\begin{array}{lr}\text { Karyawan } & \text { (Tenaga } \\
\text { Akademik/Staff/Dosen/Guru/dll }\end{array}$ & 21 & \multirow[t]{5}{*}{ Empathy } & $\begin{array}{l}\text { Institusi memberikan perhatian } \\
\text { yang penting untuk Mahasiswa }\end{array}$ \\
\hline & & ) Berpenampilan Rapih & 23 & & Tenaga \\
\hline 6 & & $\begin{array}{l}\text { Materi yang berhubungan } \\
\text { dengan pelayanan (Brosur dan } \\
\text { Pamflet) terlihat menarik }\end{array}$ & & & $\begin{array}{l}\text { Akademik/Staff/Dosen/Guru } \\
\text { memberikan perhatian kepada } \\
\text { Mahasiswa }\end{array}$ \\
\hline 7 & & $\begin{array}{l}\text { Tempat Parkir yang aman, } \\
\text { nyaman dan bersih }\end{array}$ & \multirow[t]{2}{*}{24} & & \multirow{2}{*}{$\begin{array}{l}\text { Semua } \\
\text { Akademik/Staff/Dosen/Guru } \\
\text { memahami } \\
\text { Mahasiswa }\end{array}$} \\
\hline 8 & Reliability & $\begin{array}{l}\text { Ketika Mahasiswa menghadapi } \\
\text { permasalahan, Institusi }\end{array}$ & & & \\
\hline
\end{tabular}

(Layanan

Akademik/Kemahasiswaan) menunjukkan keseriusan dalam membantu penyelesaian masalah tersebut

\begin{tabular}{|c|c|c|}
\hline 9 & & $\begin{array}{l}\text { Kualitas pelayanan yang } \\
\text { diberikan oleh Akademik dan } \\
\text { Kemahasiswaan sangat baik }\end{array}$ \\
\hline 16 & & $\begin{array}{l}\text { Bagian Pelayanan (Tenaga } \\
\text { Akademik/Kemahasiswaan/Staf } \\
\text { f) selalu terlihat percaya diri } \\
\text { dalam memberikan pelayanan }\end{array}$ \\
\hline 19 & & $\begin{array}{l}\text { Tenaga Akademik/Staff } \\
\text { mempunyai pengetahuan yang } \\
\text { baik sesuai tugas dan tanggung } \\
\text { jawabnya }\end{array}$ \\
\hline 22 & & $\begin{array}{l}\text { Institusi telah menyediakan } \\
\text { waktu pelayanan yang sesuai } \\
\text { dengan kebutuhan Mahasiswa }\end{array}$ \\
\hline 10 & $\begin{array}{c}\text { Responsive } \\
\text { ness }\end{array}$ & $\begin{array}{l}\text { Institusi memenuhi pelayanan } \\
\text { akademik dan kemahasiswaan } \\
\text { sesuai dengan waktu yang } \\
\text { dijanjikan }\end{array}$ \\
\hline 11 & & $\begin{array}{l}\text { Mahasiswa } \\
\text { kemudahan } \\
\text { menyampaikan keluhan kepada } \\
\text { bagian } \\
\text { akademik/kemahasiswaan/instit } \\
\text { usi }\end{array}$ \\
\hline 13 & & $\begin{array}{l}\text { Bagian Pelayanan (Tenaga } \\
\text { Akademik/Kemahasiswaan/Staf } \\
\text { f) memberikan pelayanan yang } \\
\text { cepat dari Mahasiswa }\end{array}$ \\
\hline 14 & & $\begin{array}{l}\text { Bagian Pelayanan (Tenaga } \\
\text { Akademik/Kemahasiswaan/Staf } \\
\text { f) selalu bersedia dan membantu } \\
\text { melayani Mahasiswa }\end{array}$ \\
\hline 12 & Assurance & $\begin{array}{l}\text { Bagian Pelayanan (Tenaga } \\
\text { Akademik/Kemahasiswaan/Staf } \\
\text { f) memberikan jawaban yang } \\
\text { tepat dan meyakinkan }\end{array}$ \\
\hline 15 & & $\begin{array}{l}\text { Bagian Pelayanan (Tenaga } \\
\text { Akademik/Kemahasiswaan/Staf } \\
\text { f) tidak pernah merasa sibuk } \\
\text { untuk melayani kebutuhan atau } \\
\text { permintaan Mahasiswa }\end{array}$ \\
\hline 17 & & $\begin{array}{l}\text { Mahasiswa selalu merasa aman } \\
\text { dalam melakukan kegiatan di } \\
\text { Institusi }\end{array}$ \\
\hline 18 & & $\begin{array}{l}\text { Bagian Pelayanan (Tenaga } \\
\text { Akademik/Kemahasiswaan/Staf } \\
\text { f) selalu bersikap sopan }\end{array}$ \\
\hline 20 & & $\begin{array}{l}\text { Institusi telah memberikan } \\
\text { informasi yang dibutuhkan oleh } \\
\text { Mahasiswa dengan jelas }\end{array}$ \\
\hline
\end{tabular}

\subsection{Karakteristik Responden}

Responden terdiri atas mahasiswa aktif Institut Teknologi Telkom Purwokerto yang sudah melakukan kegiatan perkuliahan di Institut Teknologi Telkom Purwokerto per Juni 2018 sudah lebih dari 1 Tahun. Sampel diambil dari populasi mahasiswa aktif angkatan 2016 keatas dengan jumlah populasi 1.070 mahasiswa. Mahasiswa yang dilibatkan dalam survey dengan kriteria tersebut diharapkan sudah dapat memberikan penilaian lebih kritis terhadap pelayanan dan fasilitas yang diberikan oleh institusi.

Uji Kecukupan data dilakukan dengan rumus Solvin dengan margin of error $(\mathrm{e})=0.1$ $(10 \%)$. Berdasarkan rumus tersebut, data yang perlu diambil minimum adalah 92 responden. Kuesioner yang disebarkan sebanyak 120 kuesioner dan kembali sebanyak 95 kuesioner. Dengan profil responden seperti yang tertera dalam Tabel 2, 3 dan 4.

Tabel 2. Jumlah dan Proporsi Responden Berdasarkan Jenis Kelamin

\begin{tabular}{lcc}
\hline Jenis Kelamin & Jumlah & Persentase (\%) \\
\hline Laki - Laki & 68 & 72 \\
Perempuan & 27 & 28 \\
\hline
\end{tabular}

Tabel 3. Jumlah dan Proporsi Responden Berdasarkan Program Studi

\begin{tabular}{lcc}
\hline \multicolumn{1}{c}{ Program Studi } & Jumlah & $\begin{array}{c}\text { Persentase } \\
(\%)\end{array}$ \\
\hline Informatika & 64 & 67 \\
Teknik Telekomunikasi & 31 & 33 \\
\hline
\end{tabular}

Tabel 4. Jumlah dan Proporsi Responden Berdasarkan Masa Perkuliahan

\begin{tabular}{ccc}
\hline Tingkat & Jumlah & Persentase \%) \\
\hline $\mathbf{2}$ & 22 & 23 \\
$\mathbf{3}$ & 31 & 33 \\
$\mathbf{> 4}$ & 42 & 44 \\
\hline
\end{tabular}

Dari hasil penyebaran kuesioner untuk mengetahui pemahaman pelanggan terkait implementasi ISO 9001: 2015, diperoleh hasil sebagai berikut:

a. Mengetahui bahwa institusi telah mengimplementasi ISO 9001: 2015 

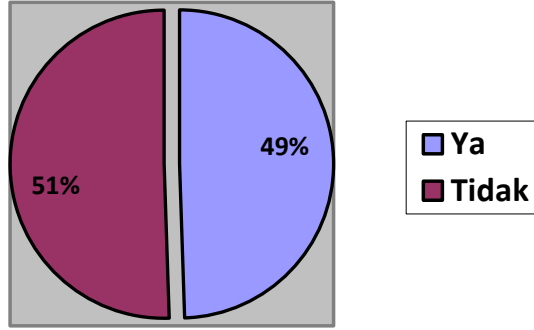

Gambar 3. Pengetahuan Tentang Implementasi ISO oleh Institusi

b. Mengetahui apa itu ISO 9001: 2015

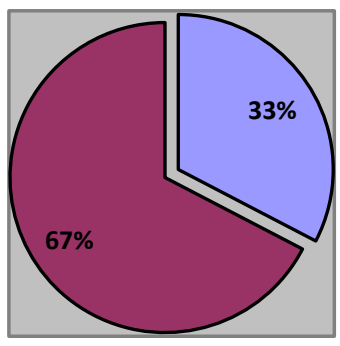

\section{$\square$ Ya}

口Tidak

Gambar 4. Pemahaman Tentang ISO 9001: 2015

Dari hasil analisis kuesioner terhadap pertanyaan pertama dapat diketahui bahwa separuh mahasiswa yaitu sebesar $51 \%$ belum mengetahui bahwa institusi telah mengimplementasikan ISO 9001: 2015, sementara sisanya sebesar $49 \%$ telah mengetahui hal tersebut. Sementara dari pertanyaan kedua diperoleh kesimpulan bahwa sebagian besar mahasiswa yaitu sebesar $67 \%$ belum mengetahui apa itu ISO 9001: 2015 dan hanya baru 33\% yang mengetahui tentang ISO 9001: 2015.

\subsection{Uji Validitas dan Reliabilitas}

Dengan menggunakan perangkat lunak SPSS dengan menggunakan korelasi Bivariate Pearson. Korelasi bivariate pearson merupakan metode yang paling sering digunakan untuk melakukan uji validitas (Wahyuni, 2014). Uji validitas dilakukan dengan ketentuan sebagai berikut:

a. Valid, jika $r_{\text {hitung }}>r_{\text {tabel }}$

b. Tidak valid, jika $r_{\text {hitung }}<r_{\text {tabel }}$

Dengan menggunakan data hasil pengukuran kuesioner diperoleh hasil seperti ditampilkan pada Tabel 5.

Tabel 5. Uji Validitas dengan Menggunakan Korelasi Bivariate Pearson

\begin{tabular}{lccc}
\hline \multirow{2}{*}{ Pertanyaan } & \multicolumn{2}{c}{$\boldsymbol{r}_{\text {hitung }}$} & \multirow{2}{*}{$\boldsymbol{r}_{\text {tabel }}$} \\
\hline item_1 & 0.772 & 0.658 & 0.202 \\
item_2 & 0.517 & 0.420 & 0.202 \\
item_3 & 0.623 & 0.674 & 0.202 \\
\hline
\end{tabular}

\begin{tabular}{|c|c|c|c|}
\hline \multirow{2}{*}{ Pertanyaan } & \multicolumn{2}{|c|}{$r_{\text {hitung }}$} & \multirow[b]{2}{*}{$r_{\text {tabel }}$} \\
\hline & Eskpektasi & Persepsi & \\
\hline item_4 & 0.641 & 0.498 & 0.202 \\
\hline item_5 & 0.711 & 0.596 & 0.202 \\
\hline item_6 & 0.815 & 0.470 & 0.202 \\
\hline item_7 & 0.721 & 0.645 & 0.202 \\
\hline item_8 & 0.908 & 0.796 & 0.202 \\
\hline item_9 & 0.834 & 0.778 & 0.202 \\
\hline item_10 & 0.878 & 0.672 & 0.202 \\
\hline item_11 & 0.868 & 0.805 & 0.202 \\
\hline item_12 & 0.871 & 0.749 & 0.202 \\
\hline item_13 & 0.825 & 0.698 & 0.202 \\
\hline item_14 & 0.854 & 0.690 & 0.202 \\
\hline item_15 & 0.827 & 0.753 & 0.202 \\
\hline item_16 & 0.806 & 0.568 & 0.202 \\
\hline item_17 & 0.840 & 0.563 & 0.202 \\
\hline item_18 & 0.869 & 0.747 & 0.202 \\
\hline item_19 & 0.884 & 0.709 & 0.202 \\
\hline item_20 & 0.821 & 0.665 & 0.202 \\
\hline item_21 & 0.859 & 0.693 & 0.202 \\
\hline item_22 & 0.860 & 0.718 & 0.202 \\
\hline item_23 & 0.858 & 0.769 & 0.202 \\
\hline item_24 & 0.772 & 0.658 & 0.202 \\
\hline
\end{tabular}

Hasil dari uji validitas diatas menyatakan bahwa hasil pengukuran yang diperoleh untuk semua item pertanyaan, baik ekspektasi maupun persepsi pelanggan hasilnya dinyatakan valid, sehingga bisa dilakukan untuk uji reliabilitas untuk tahap berikutnya. Uji reliabilitas menggunakan rumus Alpha Cronbach. Jika nilai alpha > 0.9 maka reliabilitas dikatakan sempurna (Wahyuni, 2014).

Tabel 6. Uji Reliabilitas Statistik Ekspektasi dan Persepsi Pelanggan

\begin{tabular}{lcc}
\hline & $\begin{array}{c}\text { Cronbach's } \\
\text { Alpha }\end{array}$ & $\begin{array}{c}\boldsymbol{N} \text { of } \\
\text { Items }\end{array}$ \\
\hline Ekspektasi Pelanggan & 0.972 & 24 \\
Persepsi Pelanggan & 0.939 & 24 \\
\hline
\end{tabular}

Hasil uji reliabilitas terhadap 24 item pertanyaan dalam kuesioner juga dinyatakan reliabel dan dapat digunakan hasilnya untuk pengolahan data berikutnya karena nilai alpha ekspektasi $=0.972$ dan nilai alpha persepsi $=0.939$ (alpha > 0.9), kesimpulannya reliabilitas sempurna.

\subsection{Analisis GAP 5}

Berdasarkan hasil analisis GAP 5 yaitu antara ekspektasi dan harapan dari pelanggan terhadap layanan Institut Teknologi Telkom Purwokerto diperoleh hasil seperti ditampilkan pada Tabel 7.

Tabel 7. GAP 5 (Perbandingan Ekspektasi dan Persepsi Mahasiswa)

\begin{tabular}{cccc}
\hline No & $\begin{array}{c}\text { Nilai Rata - Rata } \\
\text { Ekspektasi }\end{array}$ & $\begin{array}{c}\text { Nilai Rata - } \\
\text { Rata Persepsi }\end{array}$ & $\begin{array}{c}\text { GAP } \\
\mathbf{5}\end{array}$ \\
\hline $\mathbf{1}$ & 4.05 & 3.19 & -0.86 \\
$\mathbf{2}$ & 3.61 & 2.73 & -0.88 \\
$\mathbf{3}$ & 3.69 & 2.86 & -0.83 \\
$\mathbf{4}$ & 3.72 & 2.85 & -0.86 \\
\hline
\end{tabular}




\begin{tabular}{cccc}
\hline No & $\begin{array}{c}\text { Nilai Rata - Rata } \\
\text { Ekspektasi }\end{array}$ & $\begin{array}{c}\text { Nilai Rata - } \\
\text { Rata Persepsi }\end{array}$ & $\begin{array}{c}\text { GAP } \\
\mathbf{5}\end{array}$ \\
\hline $\mathbf{5}$ & 3.80 & 3.37 & -0.43 \\
$\mathbf{6}$ & 3.51 & 2.82 & -0.68 \\
$\mathbf{7}$ & 3.64 & 2.72 & -0.93 \\
$\mathbf{8}$ & 3.74 & 2.68 & -1.05 \\
$\mathbf{9}$ & 3.77 & 2.84 & -0.93 \\
$\mathbf{1 0}$ & 3.77 & 2.76 & -1.01 \\
$\mathbf{1 1}$ & 3.82 & 2.86 & -0.96 \\
$\mathbf{1 2}$ & 3.81 & 2.82 & -0.99 \\
$\mathbf{1 3}$ & 3.83 & 2.73 & -1.11 \\
$\mathbf{1 4}$ & 3.81 & 2.98 & -0.83 \\
$\mathbf{1 5}$ & 3.78 & 2.75 & -1.03 \\
$\mathbf{1 6}$ & 3.81 & 2.88 & -0.93 \\
$\mathbf{1 7}$ & 3.86 & 3.09 & -0.77 \\
$\mathbf{1 8}$ & 3.81 & 3.07 & -0.74 \\
$\mathbf{1 9}$ & 3.87 & 3.02 & -0.85 \\
$\mathbf{2 0}$ & 3.83 & 2.86 & -0.97 \\
$\mathbf{2 1}$ & 3.85 & 2.79 & -1.06 \\
$\mathbf{2 2}$ & 3.82 & 2.91 & -0.92 \\
$\mathbf{2 3}$ & 3.77 & 2.86 & -0.91 \\
$\mathbf{2 4}$ & 3.79 & 2.77 & -1.02 \\
\hline
\end{tabular}

Dari hasil pengolahan data pada Tabel 7 diperoleh hasil bahwa atribut no 13 dan 21 dengan nilai yaitu 1.11 dan 1.06 memiliki GAP paling tinggi dibandingkan atribut lainnya. Sehingga kepuasan mahasiswa terhadap pelayanan yang cepat dari bagian akademik/kemahasiswaan/staff dan perhatian institusi terhadap mahasiswa merupakan yang paling rendah jika dibandingkan dengan pelayanan atau fasilitas lainnya. Sementara untuk atribut no.5 dengan nilai 0.43 dan atribut no. 18 dengan nilai 0.74 memiliki GAP yang paling rendah dibanding atribut yang lainnya. Hasil ini mendeskripsikan bahwa kepuasan mahasiswa terhadap penampilah seluruh pegawai dan kesopanan bagian pelayanan (tenaga akademik/kemahasiswaan/staff) merupakan yang paling tinggi.

Dari hasil penelitian tahap awal diketahui bahwa kesadaran mahasiswa terhadap implementasi ISO 9001: 2015 masih sangat rendah, yaitu hanya $49 \%$ yang mengetahui bahwa Institusi telah mengimplementasi ISO 9001: 2015. Selain itu pengetahuan mahasiswa mengenai implementasi ISO 9001: 2015 juga masih sangat rendah, $67 \%$ mahasiswa belum mengetahui apa itu ISO 9001: 2015. Perlu ada pengenalan lebih lanjut tentang ISO 9001: 2015 dan keuntungan bagi institusi yang telah mengimplementasi ISO 9001: 2015 kepada mahasiswa. Sehingga Institusi akan memiliki nilai lebih kepada mahasiwa dan berpengaruh terhadap citra institusi bagi masyarakat umum.

Dari hasil analisis GAP 5 pada Tabel 7, institusi perlu memperbaiki kecepatan pelayanan kepada mahasiswa dari Bagian Akademik/Kemahasiswaan/Staff serta meningkatkan perhatian yang penting untuk mahasiswa. Perlu adanya upaya serius dari institusi untuk memperbaiki kecepatan pelayanan yang saat ini masih dirasakan kurang oleh mahasiswa.

Menanggapi hasil analisis survey tersebut, saat ini institusi sedang merancang pelayan terpusat sehingga semua kebutuhan mahasiswa terkait layanan dapat diselesaikan pada tempat pelayanan yang sama. Hal tersebut diharapkan mampu mempercepat layanan dan juga memperbaiki kualitas layanan. Sementara dari sisi perhatian terhadap mahasiswa, perlunya upaya pendekatan dari masing-masing dosen pembimbing akademik dalam proses perwalian serta dialog keprodian yang dilakukan secara rutin untuk melakukan evaluasi kegiatan akademis pada Institut Teknologi Telkom Purwokerto.

Penelitian ini merupakan tahap awal dari penelitian terkait evaluasi dari implementasi ISO 9001: 2015. Diharapkan hasil dari penelitian ini dapat ditindaklanjuti untuk memperoleh hasil analisis yang lebih detail dan rinci.

\section{SIMPULAN}

Dari hasil penelitian ini diperoleh kesimpulan bahwa organisasi masih perlu melakukan upaya peningkatan kepuasan pelanggan, karena 6 dari 24 atribut memiliki nilai GAP $\geq 1$. Hal tersebut menunjukkan ekspektasi dari pelanggan masih dibawah dari harapan kualitas pelayanan yang diberikan oleh institusi. Selanjutnya organisasi perlu fokus untuk melakukan perbaikan terhadap atribut yang memiliki nilai GAP paling tinggi, yaitu kecepatan layanan dari akademik/kemahasiswaan/ perpustakaan dan perhatian institusi terhadap mahasiswa. Saran untuk penelitian berikutnya agar unit pelayanan dapat difokuskan, misal pertanyaan untuk bagian akademik dan kemahasiswaan dipisahkan. Untuk memperoleh akurasi yang lebih tinggi, tingkat error dapat dikurangi sehingga jumlah sampel yang dibutuhkan akan menjadi lebih besar.

\section{DAFTAR PUSTAKA}

Cendy, B. M., Sugiono dan Hardiningtyas, D. (2015) "Analisis perancangan produk Long Leg Braces dengan pendekatan Kansei Words dan Biomekanika," Jurnal Rekayasa dan Manajemen Sistem Industri, 3(2), hal. 301-310.

Dharmawan, A. dan Wurjaningrum, F. (2014) "Rancangan perbaikan kualitas pelayanan jasa dengan metode Servqual, Importance-Performance Analysis, dan Quality Function Deployment pada Plasa Telkom Cabang Dinoyo Surabaya," Jurnal Manajemen Teori dan Terapan, 7(3), hal. 207-224.

Foster, S. T. (2016) Managing quality: integrating the supply chain. 6 ed. Upper Saddle River: Pearson Education.

Hadisaputra, S. dan Kusumah, L. H. (2017) 
"Implementasi manajemen risiko berbasis ISO 9001: 2015 dan ISO 31010: 2009 pada usaha jasa konsultasi dan pelatihan di PT. BSU penerapan Fault Tree Analysis (FTA) dan Failure Mode and Effect Analysis (FMEA)," in Prosiding Seminar Nasional Inovasi dan Aplikasi Teknologi di Industri 2017. Malang: Institut Teknologi Nasional Malang, hal. $1-12$.

Ingason, H. T. (2015) "Best project management practices in the implementation of an ISO 9001 quality management system," Procedia - Social and Behavioral Sciences. Elsevier B.V., 194, hal. 192200. doi: 10.1016/j.sbspro.2015.06.133.

Kotler, P. dan Keller, K. L. (2016) Marketing Management. 15 ed. London: Pearson Education Limited. doi: 10.1080/08911760903022556.

Nuryati, S. (2017) "Evaluasi implementasi sistem manajemen mutu ISO 9001: 2008 di puskesmas wilayah Kabupaten Sleman," Jurnal Medicoeticolegal dan Manajemen Rumah Sakit, 6(2), hal. 128-135. doi: 10.18196/jmmr.6137.

Qadri, U. A. (2015) "Measuring service quality expectation and perception using SERVQUAL: A gap analysis," Business and Economics Journal, 6(3), hal. 1-6. doi: 10.4172/2151-6219.1000162.

Qolbi, Y. (2014) "Sistem manajemen mutu ISO 9001: 2008 dalam peningkatan mutu pelayanan dan kepuasan pelanggan di Dinas Kesehatan Kota Tarakan," $e$ Journal Ilmu Pemerintahan, 2(4), hal. 3119-3130.

Semuel, H. dan Zulkarnain, J. (2011) "Pengaruh sistem manajemen mutu ISO terhadap kinerja karyawan melalui budaya kualitas perusahaan (Studi kasus PT. Otsuka Indonesia Malang)." Tersedia pada: http://repository.petra.ac.id/16144/1/Publ ikasi1_94033_1006.pdf.

Sindhuwinata, O. E. dan Felecia (2016) "Perancangan sistem manajemen mutu ISO 9001: 2015: studi kasus," Jurnal Titra, 4(2), hal. 183-190.

Soerjaningsih, T. W. (2004) "Peningkatan mutu proses Perguruan Tinggi melalui sistem mutu ISO 9000," Journal The Winners, 5(2), hal. 79-89.

Sumaedi, S. dan Yarmen, M. (2015) "Citra dan perceived value puskesmas tersertifikasi ISO 9001 (studi kasus: sebuah puskesmas di Kota Bogor)," Jurnal Standardisasi, 17(3), hal. 177-186.

Ulfi, M. A., Sudjimat, D. A. dan Wibawanto, S. (2012) "Implementasi quality management system ISO 9001: 2008 dalam pembelajaran produktif keahlian teknik mesin dan otomotif SMK," Teknologi dan Kejuruan, 35(1), hal. 1728.

doi: http://dx.doi.org/10.17977/tk.v35i1.3142.

Wahyuni, N. (2014) Uji Validitas dan Reliabilitas, QMC Binus University. Tersedia pada: http://qmc.binus.ac.id/2014/11/01/u-j-i-va-l-i-d-i-t-a-s-d-a-n-u-j-i-r-e-l-i-a-b-i-l-it-a-s/ (Diakses: 6 Agustus 2018).

Zeithaml, V. A., Berry, L. L. dan Parasuraman, A. (1990) Delivering quality service: balancing customer perceptions and expectations. New York: Free Press. 
Appendix: (Kuesioner)

\section{SURVEY KEPUASAN PELANGGAN (MAHASISWA)}

Mahasiswa yang saya hormati,

Kami Dosen dan Mahasiwa Program Studi Teknik Industri, Fakultas Teknologi Industri dan Informatika, Institut Teknologi Telkom Purwokerto, sedang melakukan penelitian terkait kepuasan Siswa atau Mahasiswa terhadap institusi (Sekolah Menengah/Akademi/Institut/Universitas) yang telah mengimplementasikan sistem manajemen mutu ISO 9001: 2015. Kuesioner ini berhubungan dengan ekspektasi dan persepsi anda sebagai Siswa atau Mahasiswa pada institusi tempat Saudara/i menempuh pendidikan. Data pengisi kuesioner akan dirahasiakan dan tidak dipublikasikan, sehingga Saudara/i dapat mengisi kuesioner dengan sesuai keadaan yang sesungguhnya dan untuk memperbaiki pelayanan dari Institusi tempat Saudara/i menempuh pendidikan.

A. Karakteristik Mahasiswa

1. Program Studi / Jurusan

2. Nama Institusi

3. Semester

:

4. Jenis Kelamin

: L / P (Coret Salah Satu)

5. Asal daerah

6. Umur

Tahun

B. Pertanyaan awal ( Beri tanda " $\sqrt{ }$ " atau " $\times$ " Pada Jawaban yang anda setujui ):

1. Apakah anda tahu jika institusi tempat anda menempuh pendidikan telah mengimplementasikan atau memperoleh sertifikasi sistem manajemen mutu ISO 9001: 2015:

\begin{tabular}{|c|c|}
\hline Tidak & Ya \\
\hline & \\
\hline
\end{tabular}

2. Apakah anda tahu apa itu ISO 9001: 2015?

\begin{tabular}{|c|c|}
\hline Tidak & Ya \\
\hline & \\
\hline
\end{tabular}

\section{Petunjuk Pengisian Kuesioner:}

1. Berikan ekspektasi anda pada kolom kiri sesuai dengan yang anda inginkan sesuai dengan pertanyaan yang disurvey

2. Persepsi menyatakan apa yang anda rasakan tentang kualitas layanan serta fasilitas sarana dan prasarana dari institusi tempat anda menempuh pendidikan

3. Ekspektasi merupakan apa yang ingin anda harapkan dari kualitas layanan serta fasilitas sarana dan prasarana dari institusi tempat anda menempuh pendidikan.

4. Kriteria Skor adalah sebagai berikut:

\begin{tabular}{|c|c|c|c|c|c|}
\hline Skor & 1 & 2 & 3 & 4 & 5 \\
\hline Ekspektasi & $\begin{array}{c}\text { Sangat Tidak } \\
\text { Penting }\end{array}$ & Tidak Penting & Cukup Penting & Penting & Sangat Penting \\
\hline Persepsi & $\begin{array}{c}\text { Sangat Tidak } \\
\text { Sesuai }\end{array}$ & Tidak Sesuai & Cukup Sesuai & Sesuai & Sangat Sesuai \\
\hline
\end{tabular}




\section{Pertanyaan Kuesioner (Beri tanda " $\sqrt{ }$ " atau " $\times$ " Pada Jawaban yang anda setujui)}

\begin{tabular}{|c|c|c|c|c|c|c|c|c|c|c|c|}
\hline \multirow{2}{*}{ No } & \multicolumn{5}{|c|}{ Ekspektasi } & \multirow{2}{*}{ Pertanyaan } & \multicolumn{5}{|c|}{ Persepsi } \\
\hline & 1 & 2 & 3 & 4 & 5 & & 1 & 2 & 3 & 4 & 5 \\
\hline 1 & & & & & & $\begin{array}{l}\text { Institusi Telah Menyediakan Perlengkapan atau Peralatan (Kelas/Laboratorium/Perpustakaan) yang } \\
\text { Modern }\end{array}$ & & & & & \\
\hline 2 & & & & & & Jumlah Petugas pelayanan akademik dan kemahasiswaan sudah sesuai dengan kebutuhan & & & & & \\
\hline 3 & & & & & & Kebersihan dan Kenyamanan Kampus memadai (Kelas, Toilet dan Area Sekitar Kampus) & & & & & \\
\hline 4 & & & & & & Fasilitas fisik (Gedung/Kelas/Laboratorium/Perpustakaan) terlihak menarik & & & & & \\
\hline 5 & & & & & & Karyawan (Tenaga Akademik/Staff/Dosen/Guru/dll) Berpenampilan Rapih & & & & & \\
\hline 6 & & & & & & Materi yang berhubungan dengan pelayanan (Brosur dan Pamflet) terlihat menarik & & & & & \\
\hline 7 & & & & & & Tempat Parkir yang aman, nyaman dan bersih & & & & & \\
\hline 8 & & & & & & $\begin{array}{l}\text { Ketika Siswa/Mahasiswa menghadapi permasalahan, Institusi (Layanan Akademik/kemahasiswaan) } \\
\text { menunjukkan keseriusan dalam membantu penyelesaian masalah tersebut }\end{array}$ & & & & & \\
\hline 9 & & & & & & Kualitas pelayanan yang diberikan oleh Akademik dan Kemahasiswaan sangat baik & & & & & \\
\hline 10 & & & & & & Institusi memenuhi pelayanan akademik dan kemahasiswaan sesuai dengan waktu yang dijanjikan & & & & & \\
\hline 11 & & & & & & $\begin{array}{l}\text { Mahasiswa diberikan kemudahan dalam menyampaikan keluhan kepada bagian } \\
\text { akademik/kemahasiswaan/institusi }\end{array}$ & & & & & \\
\hline 12 & & & & & & $\begin{array}{l}\text { Bagian Pelayanan (Tenaga Akademik/Kemahasiswaan/Staff) memberikan jawaban yang tepat dan } \\
\text { meyakinkan }\end{array}$ & & & & & \\
\hline 13 & & & & & & $\begin{array}{l}\text { Bagian Pelayanan (Tenaga Akademik/Kemahasiswaan/Staff) memberikan pelayanan yang cepat dari } \\
\text { Mahasiswa }\end{array}$ & & & & & \\
\hline 14 & & & & & & $\begin{array}{l}\text { Bagian Pelayanan (Tenaga Akademik/Kemahasiswaan/Staff) selalu bersedia dan membantu melayani } \\
\text { Mahasiswa }\end{array}$ & & & & & \\
\hline 15 & & & & & & $\begin{array}{l}\text { Bagian Pelayanan (Tenaga Akademik/Kemahasiswaan/Staff) tidak pernah merasa sibuk untuk } \\
\text { melayani kebutuhan atau permintaan Mahasiswa }\end{array}$ & & & & & \\
\hline 16 & & & & & & $\begin{array}{l}\text { Bagian Pelayanan (Tenaga Akademik/Kemahasiswaan/Staff) selalu terlihat percaya diri dalam } \\
\text { memberikan pelayanan }\end{array}$ & & & & & \\
\hline 17 & & & & & & Mahasiswa selalu merasa aman dalam melakukan kegiatan di Institusi & & & & & \\
\hline
\end{tabular}




\begin{tabular}{|c|c|c|c|c|c|c|c|c|c|c|c|}
\hline \multirow{2}{*}{ No } & \multicolumn{5}{|c|}{ Ekspektasi } & \multirow{2}{*}{ Pertanyaan } & \multicolumn{5}{|c|}{ Persepsi } \\
\hline & 1 & 2 & 3 & 4 & 5 & & 1 & 2 & 3 & 4 & 5 \\
\hline 18 & & & & & & Bagian Pelayanan (Tenaga Akademik/Kemahasiswaan/Staff) selalu bersikap sopan & & & & & \\
\hline 19 & & & & & & Tenaga Akademik/Staff mempunyai pengetahuan yang baik sesuai tugas dan tanggung jawabnya & & & & & \\
\hline 20 & & & & & & Institusi telah memberikan informasi yang dibutuhkan oleh Mahasiswa dengan jelas & & & & & \\
\hline 21 & & & & & & Institusi memberikan perhatian yang penting untuk Mahasiswa & & & & & \\
\hline 22 & & & & & & Institusi telah menyediakan waktu pelayanan yang sesuai dengan kebutuhan Mahasiswa & & & & & \\
\hline 23 & & & & & & Semua Tenaga Akademik/Staff/Dosen/Guru memberikan perhatian kepada Mahasiswa & & & & & \\
\hline 24 & & & & & & Semua Tenaga Akademik/Staff/Dosen/Guru memahami kebutuhan Mahasiswa & & & & & \\
\hline
\end{tabular}

